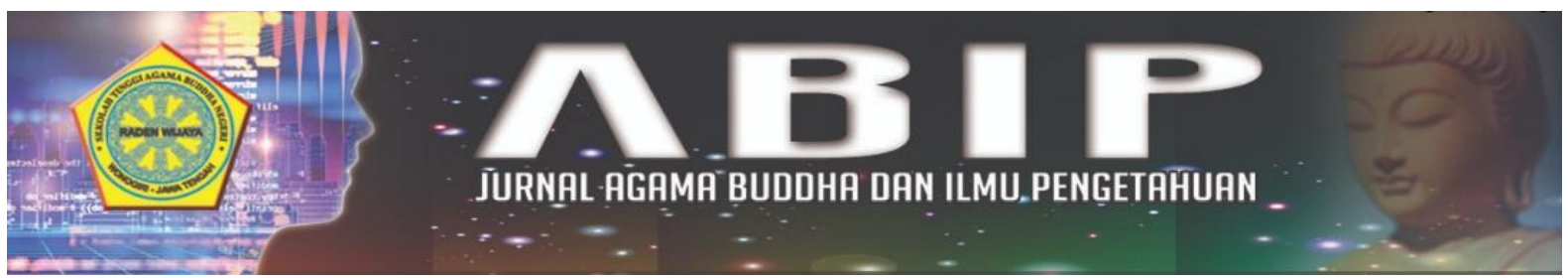

\title{
PERANAN PELATIHAN MEDITASI KESADARAN UNTUK MENINGKATKAN KEDISIPLINAN
}

\author{
Dwiyono Putranto, M. Pd \\ Sekolah Tinggi Agama Buddha Negeri Raden Wijaya \\ pak.dwiyonoputranto@gmail.com
}

\begin{abstract}
Abstrak
Penelitian ini merupakan penelitian study kualitatif, Penelitian ini dilaksanakan di Vihara Surya Karuna (Anak Asuh Dhamma Kalyana) Dk. Congger, Ds. Tunahan, Kec. Keling, Kab. Jepara. Pelatihan atau belajar meditasi kesadaran atau Mindfulness sangatlah efektif untuk dilaksanakan guna untuk meningkatkan kedisiplinan anak asuh dhamma kalyana. hal ini memang tidak dapat spontan mendapatkan hasilnya, akan tetapi seiring berjalannya pelatihan atau belajar meditasi kesadaran atau Mindfulness para anak asuh dapat dilihat hasil dan merasakan manfaatnya dari meditasi kesadaran atau mindfulness tersebut. Hasil atau manfaat dari pelatihan meditasi kesadaran atau mindfulness sudah dapat dirasakan oleh anak asuh dhamma kalyana. Bermula dari aktifitas keseharian yang positif yaitu sesuatu atau kebiasaankebiasaan yang sering ia lakukan dan menjadi peraturan di asrama sudah dapat dilakukan dengan baik dan penuh sadar.
\end{abstract}

Kata Kunci: Meditasi Kesadaran, Kedisiplinan.

\begin{abstract}
This research is a qualitative study research, This research was conducted at Vihara Surya Karuna (Foster Children of Dhamma Kalyana) Dk. Congger, Ds. Tunahan, Kec. Keling, Kab. Japan. Training or learning mindfulness meditation or mindfulness is very effective to carry out in order to improve the discipline of dhamma kalyana foster children. this is indeed not able to get results spontaneously, but as the training progresses or learns mindfulness meditation or Mindfulness the foster children can see the results and feel the benefits of the mindfulness meditation or mindfulness. The results or benefits of mindfulness meditation or mindfulness training can already be felt by dhamma kalyana foster children. Starting from positive daily activities, namely something or habits that he often does and becomes a rule in the dormitory, it can be done well and consciously.
\end{abstract}

Keywords: Mindfulness Meditation, Discipline. 


\section{PENDAHULUAN}

Kedisiplinan merupakan suatu peraturan yang simple, jelas dan tegas dimana isi dan rumusan peraturan dipikirkan secara mantap dan matang dibina dan dikembangkan secara lebih nyata. Kedisiplinan dapat melahirkan semangat menghargai waktu, akan tetapi banyak seseorang menunda-nunda waktu seakan menjadi tradisi bagi masyarakat Indonesia. Kedisiplinan bisa dikatakan sebagai kunci sukses seseorang, karena dengan disiplin maka setiap orang akan menciptakan rasa nyaman serta aman dalam menjalankan aktifitasnya. Disiplin tentu tidak akan muncul begitu saja pada diri seseorang tanpa didasari dengan penegakan peraturan yang efektif dan niat dari dalam diri.

Arikunto (2006) berpendapat bahwa peraturan tata tertib merupakan sesuatu untuk mengatur perilaku yang diharapkan terjadi pada diri seseorang. Antara peraturan dan tata tertib merupakan satu kesatuan yang tidak dapat dipisahkan sebagai pembentukan disiplin siswa dalam mentaati peraturan di kelas maupun diluar kelas karena Kedisiplinan dapat dilakukan dan diajarkan kepada anak di sekolah maupun dirumah dengan cara membuat semacam peraturan atau tata tertib yang wajib dipatuhi.

Kedisiplinan masyarakat dapat diwujudkan dengan adanya pengendalian terhadap tingkah laku dan penguasaan diri. Kedisiplinan sangat penting diterapkan sebagai prasyarat pembentukan sikap dan perilaku. Dengan demikian disiplin berarti melatih diri untuk membentuk, meluruskan atau menyempurnakan sesuatu, sebagai kemampuan mental atau karakter moral. Seseorang selalu menghendaki bahwa disiplin tidak hanya muncul karena kesadaran, tetapi ada juga karena paksaan. Disiplin yang munculkarena kesadaran disebabkan seseorang menyadari bahwa hanya dengan disiplin kesuksesan dapat terwujud.

Tidak sedikit peraturan yang ditekankan untuk meningkatkan kedisiplinan, dan disiplin melalui paksaan biasanya dilakukan dengan terpaksa pula. Keterpaksaan akan timbul karena terdapat rasa takut akan dikenakan sanksi. Dalam mewujudkan kedisiplinan tidak selamanya harus melibatkan orang lain tetapi berawal dari diri sendiri karena kedisiplinan itu timbul atas kesadaran sendiri. Penerapan disiplin berlaku bagi setiap individu dan dapat dipengaruhi oleh lingkungan, teman, dan saudara. Disiplin harus ditanamkan kepada anak sejak usia dini dalam lingkungan keluarga,yang kemudian proses tersebut berlanjut dibangku sekolah dan akhirnya dapat dikembangkan dilembaga masyarakat.

Melatih dan mendidik seseorang dalam keteraturan hidup kesehariannya di sekolah atau di asrama akan memunculkan watak disiplin. Kedisiplinan yang benar pada siswa sebaiknya diterapkan dengan penuh kesadaran terhadap diri dan penuh kasih sayang, tidak 
diidentikkan dengan kekerasan. Jika disiplin diterapkan dengan emosi, amarah, dan kekerasan maka yang muncul bukanlah kedisiplinan yang baik, namun disiplin yang terpaksa. Begitu juga sebaliknya, jika pelaksanaan disiplin dilakukan dengan penuh rasa kasih sayang, maka akan membuat kesadaran kedisiplinan itu muncul dengan sendirinya, hal ini bisa dilakukan dengan belajar melaksanakan meditasi kesadaran.

Meditasi kesadaran atau vipasana bhavana dalam agama buddha merupakan kesadaran akan 3 corak dari keberadaan pikiran dan fenomena fisik. Ketiga corak tersebut adalah anicca (ketidakkekalan), dukkha (penderitaan) dan anatta (tidak adanya diri atau aku yang kekal). Dalam bermeditasi seseorang belajar mengendalikan ketiga corak tersebut untuk membangkitkan kesadaran akan kesunyataan atas tiga corak dari pikiran dan perubahan pada tubuh. Untuk menyadari hal itu kita harus mencapai tingkatan-tingkatan dalam konsentrasi, konsentrasi ini dapat diperoleh dengan menyadari sepenuhnya segala sesuatu yang sedang terjadi pada tubuh dan pikiran.

Berdasarkan latar belakang diatas serta pengamatan penulis peneliti mengambil judul Peranan Pelatihan Meditasi Kesadaran Untuk Meningkatkan Kedisiplinan Anak Asuh Dhamma Kalyana Ds. Tunahan, Kec. Keling, Kab. Jepara. Peneliti memfokuskan pada penerapan meditasi kesadaran atau vipasana untuk meningkatkan tingkat kedisiplinan anak asuh Dhamma Kalyana.

\section{METODE}

Penelitian ini merupakan penelitian study kualitatif. Disebut kualitatif karena sifat data yang dikumpulkan bercorak kualitatif, penelitian kualitatif berupaya mengungkapkan permasalahan yang dibawa kedalam bentuk penyelesaian. Peneliti berusaha memahami arti peristiwa dan kaitannya terhadap sumber penelitian. Data yang dikumpulkan berupa wawancara, gambar, dan data lain yang diperlukan.

Penelitian ini dilaksanakan di Vihara Surya Karuna (Anak Asuh Dhamma Kalyana) Dk. Congger, Ds. Tunahan, Kec. Keling, Kab. Jepara. Menurut peneliti Lokasi tersebut sangat cocok untuk diadakan penelitian karena tergolong anak asuhnya cukup banyak dan berasal dari berbagai daerah.

Dalam penelitian ini yang diajadikan sebagai sampel adalah pembimbing meditasi yang biasa meberikan pendapatnya tentang kegiatan meditasi yang dilaksanakan bersama dengan anak asuh. Diangkatnya pembimbing meditasi dikarenakan beliau merupakan sosok ketua lembaga anak asuh dan sekaligus sebagai pembimbing meditasi di lembaga anak asuh Dhamma Kalyana. Melihat keterbatasan peneliti dan pendekatan penelitian yang digunakan, maka sampel penelitian ditentukan berdasarkan ciri dan karakteristik tertentu. Adapun ciri dan karekteristik yang 
Jurnal

Agama Buddha dan Ilmu Pengetahuan

digunakan yaitu ketua lembaga anak asuh, pembimbing meditasi, dan beberapa anak asuh Dhamma Kalyana.

\section{PEMBAHASAN}

Lembaga anak asuh dhamma kalyana memiliki sekolah jenjang Taman kanak-kanak yang dinamakan TK Dharma Putra yang merupakan sekolah tingkat kanak-kanak yang bernaung pada Lembaga Anak Asuh Dharma Kalyana. TK Dharma Putra di dirikan pada tanggal 1 Juli 2009 oleh Bhikkhu Nyanakaruno Mahathera. TK Dharma Putra terletak di Desa Tunahan, Kec. Keling, Kab. Jepara. Seluruh siswa merupakan siswa-siswi Buddhis di mana dalam kegiatan pendidikan siswa-siswi tidak dipungut biaya atau gratis.

Lembaga anak asuh dhamma kalyana berada di Desa Tunahan Kecamatan Keling, Kabupaten Jepara lebih tepatnya di Vihara Surya Karuna. lembaga anak asuh dhamma kalyana didirikan kurang lebih sejak Tahun 2014 hingga berkembang sampai saat ini, anak asuh dhamma kalyana berasal dari berbagai kalangan daerah yang berfariatif, tujuan dari lembaga anak asuh ini adalah untuk mendidik dan membangun karakter generasi muda yang berpendidikan tinggi dan memiliki kepribadian yang luhur. anak asuh dhamma kalyana masing-masing siswa berbeda pendidikan, bermula dari pendidikan tingkat SMP hingga kejenjang perguruan tinggi. selain dituntut untuk menjadi sosok yang berpendidikan, Anak asuh dhamma kalyana juga dibimbing dan diharuskan untuk memiliki sifat dan karakter yang luhur.

Meditasi kesadaran dapat disebut dengan mindfulness meditation, Meditasi ini tergolong mudah untuk dilakukan bagi pemula. Meditasi kesadaran mulai naik popularitasnya di negara bagian barat dengan nama 'Mindfulness' dalam terjemahan Bahasa Inggris yaitu Anapanasati, atau bagian dari praktik meditasi Buddha (Vipasana). Secara umum teknik meditasi kesadaran tidak hanya memusatkan perhatian pada suatu objek atau titik yang direncanakan seperti concentrated meditation, akan tetapi meditasi ini membiarkan pikiran dan perasaan melintas dalam pikiran atau yang muncul saat ini. terdapat hal yang penting dan perlu diperhatikan dalam meditasi ini yaitu kesadaran penuh, atau kemampuan untuk memusatkan perhatian pada masa sekarang tanpa memberi interpretasi, keterbukaan dan penerimaan pada masa sekarang. Dengan memahami teknik ini, meditasi kesadaran dapat berhasil dan memperoleh manfaat bagi orang yang melakukannya dengan tekun.

Banyak faktor pendukung untuk ketercapaian meditasi, diantaranya yaitu meditasi memerlukan tempat yang nyaman. kenyamanan tempat sangat diperlukan dalam berlatih meditasi, tempat berlatih meditasi ini hanya diri individu yang dapat menentukan tingkat kenyamanannya, tempat yang nyaman dimaksud yaitu tempat yang bebas dari interupsi atau gangguan, misalnya ruang yang 
tenang di dalam rumah Anda atau di halaman belakang dekat pohon atau di Vihara.

Selain kenyamanan tempat, busana yang dikenkan juga dapat mempengaruhi tingkat konsentrasi saat belajar bermeditasi. dalam hal ini saat berlatih bermeditasi perlu adanya mengenakan baju yang nyaman agar Anda tidak merasa terganggu atau terusik selama bermeditasi hanya karena busana yang terlalu ketat atau sempit. Berlatih meditasi tidaklah harus dengan jangka waktu yang lama, melainkan penentuan waktu dalam berlatih meditasi sangatlah penting. bermula dari waktu yang sedikit seiring berjalannya berlatih waktu dapat ditambahkan lebih lama.

Posisi atau gaya tubuh saat belajar bermeditasi tidak hanya berpatokan pada posisi duduk bersila, banyak sekali posisi bermeditasi yang dapat dilakukan, misalkan posisi berjalan, berdiri, duduk dikursi bahkan berbaring. Penentuan posisi tubuh sangat penting untuk mengatasi rasa kebosanan dan kejenuhan saat bermeditasi. meditasi dapat bermula dari obyek dengan cara mengalihkan pikiran terhadap kejadian yang anda alami hari ini, melainkan sejenak mengalihkan hal-hal yang sering dialami dalam keseharian. Dalam berlatih bermeditasi pikiran akan dipenuhi halhal yang sudah terjadi atau apa yang akan terjadi nanti dan perasaan atau pikiran menjadi gelisah. Hal ini merupakan hal yang biasa dialami oleh pemula. Kegelisahan ini dapat diatasi dengan cara mengamati pikiran Anda yang sedang sibuk dan biarkan saja berlalu sambil terus kendalikan dan Kenali perasaan tersebut dan dapat dialihkan perhatian kepada postur tubuh sambil berusaha menemukan titik kenyamanan.

Pentingnya memperhatikan nafas saat bermeditasi, hal ini dapat dilakukan dengan memfokuskan tingkat kesadaran pada nafas dengan memperhatikan setiap tarikan dan embusan keluar masuknya nafas. Rasakan aliran napas yang masuk ke dalam tubuh, mengisi paru-paru Anda, dan keluar melalui mulut. Berusahalah bernapas lebih panjang dan lebih dalam. Tarikan napas panjang akan mengendalikan dan mengalirkan rasa nyaman ke seluruh tubuh dan pikiran. hal ini dapat dilatih atau diterapkan sebagai cara berlatih meditasi kesadaran.

Selama bermeditasi perlu adanya pengendalian pikiran, ingatkan diri sendiri bahwa pengendali pikiran adalah anda sendiri atas pikiran dan emosi yang telah muncul. Ketika muncul pikiran yang begitu cepat dan bukan harapan, cobalah untk melepaskan dan jangan mengarahkan perhatian Anda ke sana. Pemahaman ini bisa membantu belajar bermeditasi dengan menyadari bahwa individu dapat mengubah pikiran dan melupakannya sertakembali kepada nafas. Amati kembali keluar masuknya nafas setiap kali perhatian Anda teralihkan oleh suara, pikiran dan berusaha kembalikan fokus Anda pada napas jika muncul pikiran dan emosi yang mengganggu. 
Perhatian semacam ini mengembangkan kesadaran, kejernihan dan menerima kondisi yang ada. Jika kita tidak sadar pada momen-momen kini, maka kita tidak hanya kehilangan sesuatu yang sangat berharga di dalam hidup kita, tetapi juga gagal meraih kesempatan untuk tumbuh dan berkembang. Tujuan dari meditasi juga dapat membantu manusia untuk dapat belajar memahami fenomena secara tepat sehingga dapat menghilangkan fantasi pikiran yang sering memberikan pandangan yang salah mengenai realitas. Oleh sebab itu, meditator dapat memahami banyaknya kesulitan yang akan dihadapi jika pikiran terkotori serta dapat lebih memahami tentang dirinya.

Lenyapnya seluruh penderitaan adalah tujuan pertama dari meditasi, maka pencapaian perasaan yang positif adalah tujuan yang kedua, dan tujuan yang ketiga adalah pemusatan pikiran (konsentrasi) dan pandangan terang, serta kebebasan atau tidak terikat. Konsentrasi (pemusatan pikiran) adalah kemampuan untuk memegang pemusatan perhatian dengan kuat pada suatu objek tertentu dalam masa waktu yang diperpanjang.

Teknik berlatih meditasi ini adalah untuk kesadaran yang dapat membantu terfokus pada kehidupan yang sedang berlangsung saat ini. Pikiran seseorang cenderung tertarik ke masa depan atau kembali ke masa lalu, tetapi tubuh Anda selalu berada dalam kondisi saat sekarang. Dengan berlatih meditasi berkesadaran seseorang dapat pula menjadi sadar akan adanya peraturan yang mengharuskan individu untuk disiplin dalam mentaati peraturan atau menjalankan sesuatu.

Seseorang yang Patuh peraturan bias dikatakan sebagai Kedisiplinan yang dapat mengarahkan diri pada setiap tujuan yang diinginkan melalui latihan dan peningkatan kemampuan yang datang dari hati nurani disertai kerelaan untuk menaati peraturan. Taat peraturan merupakan salah satu adanya kedisiplinan yang berkembang melalui kewajiban pribadi dalam hidup bermasyarakat. Kedisiplinan bisa juga berawal dari tingkat kemampuan dan kemauan mengendalikan diri dalam mengamalkan nilai, ketentuan, peraturan dan tata tertib yang berlaku di sekolah, masyarakat dan negara.

Pentingnya kedisiplinan ditanamkan sejak dini untuk anak atau generasi muda, karena kedisiplinan dapat muncul dari banyak faktor, diantaranya rekan sejawat dan dari dalam diri sendiri. kedisiplinan juga tidak hanya terhadap peraturan yang dibuat atau yang berkaitan dengan hukum melainkan kedisiplinan terhadap aktifitas kecil atau yang berhubungan dengan kepribadiannya juga sangat penting untuk ditanamkan sejak dini.

Peran kedisiplinan sangatlah bervariatif, dapat bermula dari adanya keterpaksaan akan aturan yang di tetapkan, dapat juga muncul karena adanya kesadaran akan peraturan yang di tetapkan.akan tetapi dalam hal ini kesadaran akan kedisiplinan yang 
Jurnal

Agama Buddha dan Ilmu Pengetahuan

muncul dari dalam diri sangatlah diharapkan atau diperlukan bagi anak muda atau generasi muda dari jenjang pendidikan dan dalam kehidupan sehari-hari.

Untuk mencapai kesadaran akan kedisiplinan, meditasi kesadaran sangatkan penting untuk diterapkan pada jenjang pendidikan kususnya anak asuh dhamma kalyana. Saat ini anak asuh dhamma kalyana sudah memiliki jadwal berlatih meditasi secara rutin, dalam hal ini dibimbing oleh bapak Suharyanto. Kegiatan berlatih meditasi dilakukan secara rutin yaitu satu kali dalam satu minggu sehingga anak asuh dhamma kalyana dapat berlatih dengan rutin dan sungguh-sungguh.

Teknik meditasi yang diajarkan sangatlah bervariatif yaitu berawal dari meditasi duduk bersila dengan memperhatikan keluar masuknya nafas, menyadari akan pergerakan tubuh saat bermeditasi, menyadari perubahan pikiran. Teknik ini diterapkan tiap kali berlatih meditasi kesadaran hingga anak asuh dapat mengkondisikan pikiran, nafas, dan gerak tubuh saat berlatih meditasi.

Selain itu terdapat teknik lain yang hendak diterapkan yaitu berlatih sadar akan segala sesuatu yang dilakukan saat ini. Bermula dari hal sekecil apapun yaitu tata cara meletakkan sepatu atau sandal pada tempatnya saat selesai dikenakan, kesadaran akan makan bersama dengan rekan asrama hinggga saat mengunyah makanan dengan penuh sadar, kesadaran mencuci atau membersihkan peralatan makan saat selesai digunakan, kesadaran akan kebersihan lingkungan asrama dan lingkungan sekitar, sadar akan adanya kebersamaan dalam sebuah lingkup asrama maupun diluar, kesadaran akan waktu belajar dan waktu untukberibadah, dan kesadaran akan adanya peraturan yang ditetapkan pada lingkungan asrama maupun lingkungan sekitar dan disekolah.

Kesadaran-kesadaran dalam hal kecil ini sangatlah penting untuk dilatih karena merupakan sesuatu hal yang pasti dilakukan dari jenjang pendidikan hingga dunia kerja nantinya. Kesadaran ini dilatih dari belajar bermeditasi kesadaran atau Mindfulness supaya para anak asuh dapat mengenal diri sendiri hingga lingkungannya dengan baik dan dapat menjadikan diri individu disiplin dan patuh akan segala peraturan yang berlaku, baik peraturan dalam rumah, asrama, sekolah maupun peraturan Negara tanpa adanya keterpaksaan.

Pelatihan atau belajar meditasi kesadaran atau Mindfulness sangatlah efektif untuk dilaksanakan guna untuk meningkatkan kedisiplinan anak asuh dhamma kalyana. hal ini memang tidak dapat spontan mendapatkan hasilnya, akan tetapi seiring berjalannya pelatihan atau belajar meditasi kesadaran atau Mindfulness para anak asuh dapat dilihat hasil dan merasakan manfaatnya dari meditasi kesadaran atau mindfulness tersebut. meditasi kesadaran atau mindfulness akan terus dikembangkan dan dilatih anak asuh dhamma 
kalyana guna untuk mencapai kualitas batin dan rasa sadar akan kedisiplinan.

Hasil atau manfaat dari pelatihan meditasi kesadaran atau mindfulness sudah dapat dirasakan oleh anak asuh dhamma kalyana. Bermula dari aktifitas keseharian yang positif yaitu sesuatu atau kebiasaankebiasaan yang sering ia lakukan dan menjadi peraturan di asrama sudah dapat dilakukan dengan baik dan penuh sadar. Kegiatan seharihari dapat dilaksanakan dengan bersama-sama secara terjadwal dan penuh semangat dan penuh sadar.

Sadar akan segala apa yang dilakukan dapat mencapai buah yang besar, bukanlah suatu keadaan mistik diluar pengetahuan yang dapat dicapai oleh tiap manusia. Akan tetapi suatu hal yang sangat sederhana dan biasa serta sangat dikenal oleh kita semua. Hal ini dikenal dengan nama perhatian sebagai salah satu pekerjaan pokok dari kesadaran, tanpa adanya kesadaran tidak akan ada yang namanya penglihatan.

\section{SIMPULAN}

Berdasarkan hasil penelitian dapat disimpulkan bahwa meditasi kesadaran dapat dimulai dari hal kecil yang penting untuk dilatih karena merupakan sesuatu hal yang pasti dilakukan dari jenjang pendidikan hingga dunia kerja nantinya. Kesadaran ini dilatih dari belajar bermeditasi kesadaran atau Mindfulness supaya para anak asuh dapat mengenal diri sendiri hingga lingkungannya dengan baik dan dapat menjadikan diri individu disiplin dan patuh akan segala peraturan yang berlaku, baik peraturan dalam rumah, asrama, sekolah maupun peraturan Negara tanpa adanya keterpaksaan.

Pelatihan atau belajar meditasi kesadaran atau Mindfulness sangatlah efektif untuk dilaksanakan guna untuk meningkatkan kedisiplinan anak asuh dhamma kalyana. hal ini memang tidak dapat spontan mendapatkan hasilnya, akan tetapi seiring berjalannya pelatihan atau belajar meditasi kesadaran atau Mindfulness para anak asuh dapat dilihat hasil dan merasakan manfaatnya dari meditasi kesadaran atau mindfulness tersebut. meditasi kesadaran atau mindfulness akan terus dikembangkan dan dilatih anak asuh dhamma kalyana guna untuk mencapai kualitas batin dan rasa sadar akan kedisiplinan.

Hasil atau manfaat dari pelatihan meditasi kesadaran atau mindfulness sudah dapat dirasakan oleh anak asuh dhamma kalyana. Bermula dari aktifitas keseharian yang positif yaitu sesuatu atau kebiasaankebiasaan yang sering ia lakukan dan menjadi peraturan di asrama sudah dapat dilakukan dengan baik dan penuh sadar. Kegiatan seharihari dapat dilaksanakan dengan bersama-sama secara terjadwal dan penuh semangat dan penuh kesadaran sehingga batin dan kualitas diri menjadi lebih baik dan berkembang.

\section{DAFTAR PUSTAKA}


A.S. Moenir, (1983). Pendekatan Manusiawi dan Organisasi terhadap Pembinaan Kepegawaian, Jakarta: PT. Gunung Agung.

Arikunto, S. (2006). Metode Penelitian Kualitatif. Jakarta: Bumi Aksara.

Burhan, B. H. M. (2007). Penelitian Kualitatif: Komunikasi, Ekonomi, Kebijakan Publik, dan Ilmu Sosial. Jakarta: Kencana Prenama Media Group.

Bambang Sujiono dan Yuliani Nurani Sujiono, (2005). Mencerdaskan Perilaku Anak Usia Dini Panduan Bagi Orang Tua dalam membina Perilaku Anak Sejak Dini. Jakarta: Alex Media Komputindo.

Conny Semiawan, (2002). Pendidikan Keluarga Dalam Era Global, Jakarta: PT Prenhallindo.

Evi Chumaidah, (2011). Upaya Peningkatan Kedisiplinan Shalat Berjema'ah Di Madrasah Tsanawiyah Negeri Sidoarjo, Skripsi S-1 Pendidikan Surabaya: Perpustakaan IAIN Sunan Ampel Surabaya.

Jon, Kabat, (2013). Where You Go There You Are, Meditasi Perhatian Murni Dalam Kehidupan Seharian, Jakarta: Karaniya.

Moleong, Lexy J. (007). Metode penelitian Kualitatif. Bandung: PT. Remaja.
Muhammad Mustari, (2014). Nilai Karakter Refleksi Untuk Pendidikan. Jakarta: Raja Grafindo Persada.

Oka Disputhera, (2004). Meditasi II, Pendidikan Tinggi Agama Buddha, Jakarta: Penerbit Vajra Dharma Nusantara.

Piet A. Sahertian, (1994) DimensiDimensiAdministrasi Pendidikandi Sekolah. Jakarta: Usaha Nasional.

Sukarna, (1992). Dasar-Dasar Manajemen, Bandung: Mandar Maju.

Sukma dinata, nana, S. (2005). Landasan psikologi pendidikan proses pendidikan. Jakarat; PT Remaja Rosdakarya.

Sugiyono. (2011). Metodologi Penelitian Pendidikan (Pendekatan kuantitatif, Kualitatif dan $R \& D$ ). Bandung: Alfabeta.

Syamsul Bahri Djamarah, (2008). Rahasia Sukses Belajar, Jakarta: Rineka Cipta.

Somdet Phra Buddhagosacariya (Nanavara Thera), (2004). Samadhi Pencerahan Agung, (Jakarta: Penerbit Sri Manggala.

Thomas W.Phelan, (2009). Magic Cara Ajaib Mendisiplinkan Anak 2-12 Tahun, (Yogyakarta: ANDI. 